\title{
GAMBARAN PENGETAHUAN IBU TENTANG VAKSIN HUMAN PAPILOMA VIRUS (HPV) SEBAGAI PENCEGAHAN KANKER LEHER RAHIM DI DUSUN I DESA MANGGA KABUPATEN LANGKAT TAHUN 2016
}

\author{
Setia Sihombing \\ Prodi DIII Kebidanan STIKes Putra Abadi Langkat, tiasihombing@gmail.com
}

\section{Kata Kunci:}

Vaksin HPV, Kanker Leher Rahim

\begin{tabular}{l}
\hline INFO ARTIKEL \\
\hline RiwayatArtikel: \\
Diterima: $5-01-2018$ \\
Disetujui: $30-01-2018$ \\
\hline
\end{tabular}

\begin{abstract}
ABSTRAK
Abstrak: Jumlah pengidap kanker serviks seluruh dunia mencapai 2,2 juta jiwa per tahun. Yayasan kanker Indonesia (2007) menyebutkan angka 2 yang lebih hebat, 500.000 perempuan indonesia terdeteksi telah mengidap kanker serviks setiap tahun dan separuhnya meninggal akibat kanker serviks tersebut dan $70 \%$ pasien kanker serviks di Rumah sakit datang sudah dalam stadium lanjut. Kanker leher rahim pada umumnya dapat dicegah secara primer yaitu dengan vaksinasi. Tujuan Penelitian ini adalah untuk mengetahui Gambaran Pengetahuan Ibu tentang Vaksin HPV Sebagai Pencegahan Kanker Leher Rahim di dusun I Desa Mangga Kabupaten Langkat Tahun 2016. Jenis Penelitian ini adalah bersifat deskriptif, dengan populasi adalah ibu Pasangan Usia Subur di Dusun I Desa mangga sebanyak 30 orang dan pengumpulan data secara primer dengan membagikan kuesioner. Dari hasil Penelitian diperoleh mayoritas responden berpengetahuan kurang sebanyak 24 orang $(66,6 \%)$, mayoritas berpendidikan dasar sebanyak 21 responden $(58,3 \%)$ dan mayoritas tidak pernah memperoleh informasi sebanyak 17 responden $(47,2 \%)$. Disimpulkan bahwa pengetahuan responden dipengaruhi oleh pendidikan dan sumber informasi oleh karena itu disarankan kepada tenaga kesehatan untuk lebih banyak memberikan informasi.
\end{abstract}

Abstract: The number of people with cervical cancer all over the world reached 2.2 million people per year. Cancer Foundation, Indonesia (2007) mentions a great number 2, 500,000 Indonesian women have contracted cervical cancer detected each year and half die of cervical cancer, and $70 \%$ of cervical cancer patients at the hospital are coming already in the advanced stage. Cervical cancer in General can be prevented with vaccination in primary. The purpose of this research is to know the description of the mother's Knowledge about HPV vaccine as a prevention of cervical cancer in the hamlet of Langkat Regency Mango village Year 2016. Type of this research is descriptive, with a population of Fertile Age Couples was the mother in hamlet village mango as many as 30 people and the collection of primary data by distributing questionnaires. Of research results obtained a majority of respondents knowledgeable less as much as 24 people (66.6\%), the majority of educated basis as much as 21 respondents (58.3\%) and the majority never gain as much information as the 17 respondents (47.2\%). It was concluded that the respondent's knowledge is influenced by education and information resources are therefore recommended to health workers to give more information 


\section{A. LATAR BELAKANG}

Kanker servik teramsuk penyakit pembunuh wanita rangking 1 di dunia. Jumlah pengidap kanker serviks seluruh dunia mencapai 2,2 juta jiwa per tahun. Di negara berkembang kanker serviks menempati urutan teratas sebagai penyebab kematian akibat kanker di usia reprodukstif. Hampir 80 \% kasus berada di negara berkembang. Departemen kesehatan Republik Indonesia menyatakan bahwa sampai saat ini terdapat 100 kasus kanker serviks setiap 100.00o penduduk Indonesia per tahun. Sementara data yayasan kanker Indonesia (2007) menyebutkna angka 2 yang lebih hebat, 500.000 perempuan indonesia terdeteksi telah mengidap kanker serviks setiap tahun dan separuhnya meninggal akibat kanker serviks tersebut. Data departemen Kesehatan Republik Indonesia menyebutkan 70 \% pasien kanker serviks di Rumah sakit datang sudah dalam stadium lanjut. Inilah yang membuat angka harapan hidup mereka di bawah 50 \% ketika memasuki perawatan Rumah Sakit (Nurcahyo, Jalu, 2010)

Di Sumatera utara diperoleh data dari dinas Kesehatan propinsi jumlah penderita kanker serviks pada tahun 2000 sebanyak 548 kasus, tahun 2001 sebanyak 683 kasus. Di RSUD dr. Pirngadi Medan tahun 2007 sebanyak 345 kasus, tahun 2008 sebanyak 25 kasus, tahun 2009 sebanyak 48 kasus dan tahun 2010 sebanyak 40 kasus. (Depkes, 2010).

Proses perkembangan penyakit kanker serviks membutuhkan waktu yang cukup lama yaiti sekitar 5-20 tahun mulai dari terinfeksi HPV sampai terjadinya kanker. Apabila seorang wanita terdiagnosa menderita kanker serviks pada usia 55 tahun, kemungkinan wanita terseut sudah terinfeksi virus hpV saat masih berusia 35 tahun. Untuk itu sangat diperlukan pencegahan kanker serviks sedini mungkin terutam wanita pasangan usia subur yang mutlak telah aktif melakukan hubungan seksua, menggunakan kontrasepsi untuk menunda atau menghambat seperti pemakaian pil kontrasepsi dan melahirkan (Wijaya, 2010).

Kanker leher rahim pada umunya dapat dicegah secara primer, sekunder dan tertier. Pencegahn secara primer yaitu menjaga kebersihan dengan pola hidup seha, dengan menghindari faktor-faktor resiko seperti prilaku seks yang buruk, merokok, vaksinasi, komposisi nutrisi raional. Pencegahan sekunder termasuk skrining dan deteksi dini untuk menemukan kasus- kasus dini sehingga kemungkinan penyembuhan dapat ditingkatkan serta pencegahn tersier dengan pengobatan untuk mencegah komplikasi klinik dan kematian awal. (Rasjidi, 2009).

Pada tanggal 8 juni 2006, FDA (The U.S and Drug Administration) telah mengesahkan vaksin HPV dan sudah mendapat ijin edar dari BPOM RI di Indonesia. Vaksin ini mempunyai efektifitas 96$100 \%$ untuk mencegah kanker leher rahim yang disebabkan oleh HPV tipe 16 dan 18. (Rusmil, 2008).

Berdasarkan latar belakang tersebut peneliti tertarik untuk melakukan penelitian tentang Gambaran Pengetahuan Ibu tentang Vaksin HPV Sebagai Pencegahan Kanker Leher Rahim di dusun I Desa Mangga Kabupaten Langkat Tahun 2016.

\section{B. METODE PENELITIAN}

Desain penelitian yang digunakan dalam penelitian ini adalah deskriptif untuk menggambarkan Pengetahuan Ibu tentang Vaksin HPV sebgaia Pnecegahan Kanker Leher Rahim di Dusun I Desa Mangga Kabupaten Langkat Tahun 2016.

Populasi dalam penelitian ini adlah seluruh ibu pasangan usia subur yang ada di Dusun I Desa Mangga Kabupaten Langkat Tahun 2016 yaitu sebanyak 36 orang sekaligus menjadi sampel ( Total Sampling).

Metode pengumpulan data adalah data primer. Peneliti menggunakan alat pengumpulan data berupa formulir kuesioner pengetahuan ibu tentang vaksin HPV sebagai pencegahan kanker leher rahim meliputi pengertian kanker leher rahim 5 soal, mengenai vaksin HPV 5 soal, pengertian Human Papiloma Virus 5 soal dan hubungan Human Pappiloma virus dengan kanker leher rahim sebanyak 5 soal.

Aspek pengukuran pengetahuan dengan memberikan skor 5 untuk jawaban yang benar dana skor o untuk jawaban yang salah sehingga pengetahuan dapat dikategorikan menjadi :

1. Baik, bila pertanyaan dijawab benar 80$100 \%$ (dapat menjawab 16-20 soal dengan benar)

2. Cukup, bila pertanyaan dijawab benar 6075 \% (dapat menjawab 12-15 soal dengan benar)

3. Kurang , bila pertanyaan dijawab benar o$55 \%$ (dapat menjawab < 12 soal dengan benar)

\section{HASIL DAN PEMBAHASAN}

\section{Hasil Penelitian}

Hasil penelitian yang dialkukan adalah:

\section{TABEL 1}

Distribusi pengetahuan responden entang Vaksin HPV sebagai Pencegahan Kanker Leher Rahim di Dusun I Desa mangga Tahun 2016

\begin{tabular}{ccc}
\hline Pengetahuan & F & \% \\
\hline Baik & 2 & 5,6 \\
Cukup & 10 & 27,8 \\
Kurang & 24 & 66,6 \\
Jumlah & 36 & 100 \\
\hline
\end{tabular}


Dari Tabel 1 diperoleh mayoritas responden berpengatahuan kurang sebanyak 24 orang $(66,6 \%)$

\section{TABEL 2}

Distribusi pengetahuan responden tenga vakisn HPV sebagai pencegahan kanker leher rahim berdasarkan pendidikan

\begin{tabular}{|c|c|c|c|c|c|c|c|c|}
\hline \multirow{3}{*}{$\begin{array}{c}\text { Pengeta } \\
\text { huan }\end{array}$} & \multicolumn{4}{|c|}{ Pendidikan } & & & \multicolumn{2}{|c|}{ Total } \\
\hline & & Dasar & & engah & & ggi & & \\
\hline & $\mathrm{f}$ & $\%$ & $\mathrm{~F}$ & $\%$ & $\mathrm{~F}$ & $\%$ & f & $\%$ \\
\hline Baik & $\mathrm{O}$ & o & 1 & 2,7 & 1 & 2 & 2 & 5,6 \\
\hline Cukup & 3 & 8,3 & 7 & 19,5 & O & 7 & 10 & 27,8 \\
\hline Kurang & 21 & 58,3 & 3 & 8,4 & O & $\begin{array}{l}0 \\
0\end{array}$ & $\begin{array}{l}2 \\
4\end{array}$ & 66,6 \\
\hline Total & 24 & 66,6 & 11 & 30,6 & 1 & 2,7 & 36 & 100 \\
\hline
\end{tabular}

Dari tabel 2 diperoleh bahwa dari 24 responden (66,6\%) yang berpengetahuan kurang mayoritas berpendidikan dasar sebanyak 21 responden $(58,3 \%)$

\section{TABEL 3}

Distribusi pengetahuan repsonden tentang vaksin HPV sebagai pencegahan Kanker Leher Rahim berdasarkan sumber informasi

\begin{tabular}{ccccccc}
\hline Pengetahuan & \multicolumn{3}{c}{ Sumber Informasi } & \multicolumn{2}{c}{ Total } \\
\hline & \multicolumn{9}{c}{ Pernah } & \multicolumn{2}{c}{ Tidak } \\
& F & $\%$ & F & $\%$ & f & $\%$ \\
Baik & 2 & 5,6 & O & O & 2 & 5,6 \\
Cukup & 8 & 22,1 & 2 & 5,6 & 10 & 27,8 \\
Kurang & 7 & 19,5 & 17 & 47,2 & 24 & 66,6 \\
Total & 17 & 47,2 & 19 & 52,8 & 36 & 100 \\
\hline
\end{tabular}

Dari tabel 3 diperoleh bahwa dari 24 responden $(66,6 \%)$ yang berpengetahuan kurang mayoritas tidak pernah memperoleh informasi sebanyak 17 responden $(47,2 \%)$.

\section{Pembahasan}

Dari hasi penelitian diperoleh mayoritas responden berpengatahuan kurang sebanyak 24 orang (66,6\%). Menurut Notoadmodjo (2003), menyatakan bahwa pengetahuan merupakan hasil dari tahu dan hal ini terjadi setelah orang melakukan penginderaan terhadap suatu objek tertentu. Pengetahuan diperlukan sebagai dorongan sikap dan perilaku setiap hari, sehingga dapat dikatakan bahwa pengetahuan meruapak stimulasi terhadap tindakan.

Menurut asumsi peneliti pengetahuan responden kurang disebabkan karena pendidikan responden yang rendah dan kurangnya informasi yang diperoleh serta kurangnya promosi penyuluhan tentang pentingnya vaksin HPV untuk mencegah kanker serviks. Dari hasil penelitian diperoleh bahwa dari 24 responden $(66,6 \%)$ yang berpengetahuan kurang mayoritas berpendidikan dasar sebanyak 21 responden $(58,3 \%)$.

Menurut asumsi peneliti hasil penelitian ini sesuai dengan pendapat hidayat (2005) yang menyatakan pendidikan merupakan penuntun manusia untuk berbuat dan mengisi kehidupannya yang dapat digunakan untuk mendapatkan informasi sehingga dapat meningkatkan kualitas hidup. Semakin tinggi pendidikan seseorang makin mudah menerima informasi dan makin bagus pengetahuan yang dimiliki sehingga penggunaan komunikasi dapat secara efektif akan dapat dilakukannya. Hal ini terbukti bahwa pendidikan dasar mempunyai pengetahuan yang kurang.

Dari hasil penelitian diperoleh bahwa dari 24 responden $(66,6 \%)$ yang berpengetahuan kurang mayoritas tidak pernah memperoleh informasi sebanyak 17 responden (47,2\%). Menurut Notoadmodjo (2003) bahwa informasi yang diperoleh dari berbagai sumber informasi mempengaruhi tingkat pengetahuan seseorang. Jika seseorang banyak mendapatkan informasi cenderung memiliki pengetahuan yang tinggi.

Menurut asumsi peneliti bahwa hasil penelitian sesuai dengan teori karena terbukti bahwa mayoritas responden pengetahuan kurang tidak pernah memperolh informasi. Karena informasi dapat merubah pemikiran dan sikap individu dalam bertindak. Informasi yang diperoleh dengan pengetahuan baik adalah dari tenaga kesehatan karena tenaga kesehatan lebih mengerti dan memahami tentang kesehatan dan cara penyampaian dalam bentuk promosi dapat cepat meyakinkan masyarakat.

\section{SIMPULAN DAN SARAN}

\section{Kesimpulan}

Berdasarkan hasil penelitian mengenai gmabaran penegtahuan ibu tentang VaksinHPV sebagai Pencegahan Kanker Leher Rahim di Dusun I Desa Mangga Kabupaten Langkat Tahun 2016 dapat disimpulkan bahwa mayoritas responden berpengetahuan kurang tentang vaksin HPV. Responden yang berpengetahuan kurang mayoritas berpendidikan dasar dan mayoritas tidak pernah memperoleh informasi.

\section{Saran}

Setelah disimpulkan penelit memberikan saran :

a. Bagi para ibu diharapkan untuk lebih meningkatkan pengetahuan tentang manfaat penggunaan Vaksin HPV dengan mencari sumber informasi yang lebih banyak, agar ibu dapat terhindar dari penyakit kanker servik dan menjalani pola hidup sehat bagi diri sendiri

b. Bagi petugas kesehatan untuk memberikan informasi yang jelas dan benar kepad ibu tentang vaksin HPV sebagai pencegahan kanker leher rahim

c. Bagi peneliti selanjutnya disarankan agar dapat melakukan penelitian kepada aspek yang lebih lengkap untuk menyempurnakan penelitian ini. 


\section{UCAPAN TERIMA KASIH}

Penulis mengucapkan terima kasih kepada ketua STIKes Putra Abadi Langkat yang telah memberikan dukungannya, terima kasih pada LPPM STIKes Putra Abadi Langkat yang telah mendanai penelitian ini dan terima kasih kepada bapak kepala desa Mangga yang telah memberi ijin untuk meneliti di daerahnya.

\section{DAFTAR RUJUKAN}

Depkes RI. 2010. Penanggulangan Kanker Serviks dengan Vaksin HPV. Departemen Kesehatan RI

Djamin. 2009. Hubungan Keberadaan Human Papilloma Virus sebelum dan sesudah Pengobatan dengan Respon Terapi. Tesis Bagian Obstetri Gynekologi FK-USU-Medan

Dianandan R. 2009. Mengenal seluk Beluk Kanker. Yogyakarta.

Hidayat, A. 2005. Pengantar Ilmu Keperawatan. Jakarta. Salemba Medika

Nurcahyo, Jalu. 2010. Awas bahaya kanker rahim dan kanker payudara. Yogyakarta: Wahana Totalita Publisher.

Notoadmodjo, Soekidjo.2009. Promosi Kesehatan: Teori dan Aplikasi. Jakarta: PT Rineke Cipta.

Nurwijaya,Hartati. 2010. Cegah dan deteksi Kanker Leher Rahim. Jakarta: Alex Media Komputindo.

Rasjidi, I. 2009. Deteksi Dini dan Pencegahan Kanker Pada Wanita. Jakarta: Sagung Seto

Rusmil, K. 2008. Human Papilloma Virus Edisi 3. Jakarta. Badan Penerbit Ikatan Anak Indonesia.

Sukardja, I Dewa Gede, 2010. Onkologi Klinik. Surabaya: Air Langga University Press.

Tjokronegoro, Arjatmo. 2009. Deteksi Dini Kanker. Jakarta: FKUI

Wijaya, D. 2010. Pembunuh Ganas itu Bernama Kanker Serviks. Yogyakarta: Sinar Kejora

\section{PROFIL PENULIS UTAMA}

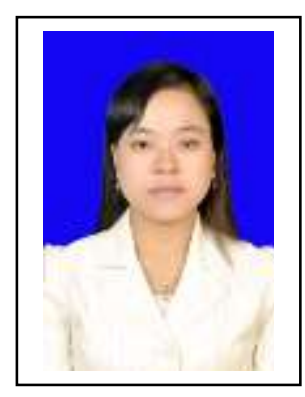

Penulis bernama lengkap "Setia Sihombing, SST, M.Kes", lahir di Janji Marapot, 28 januari 1984. Adapun riwayat pendidikan sebagai berikut:

D.III Kebidanan STIKes Putra Abadi Langkat

D.IV Bidan Pendidik Poltekes Medan S2 Kesehatan Masyarakat URINDO Jakarta 